\title{
Role of black carbon in the formation of primary organic aerosols: Insights from molecular dynamics simulations
}

\author{
Xiaoqi Zhou ${ }^{1}$, Yulu Zhou ${ }^{1}$, Sylvain Picaud ${ }^{2}$, Michel Devel ${ }^{3}$, Jesús Carrete ${ }^{4}$, Georg K. H. Madsen ${ }^{4}$, and \\ Zhao Wang ${ }^{1,4}$ \\ ${ }^{1}$ Department of Physics, Guangxi University, 530004 Nanning, China \\ ${ }^{2}$ Institut UTINAM, CNRS UMR 6213, Université Bourgogne Franche-Comté, 25030 Besançon, France \\ ${ }^{3}$ FEMTO-ST Institute, UBFC, CNRS, ENSMM, 15B avenue des Montboucons, 25030 Besançon, France \\ ${ }^{4}$ Institute of Materials Chemistry, TU Wien, 1060 Vienna, Austria
}

Correspondence: Zhao Wang (zhao.wang@tuwien.ac.at)

Abstract.

Many studies on the mixing state of suspended particulate matters (PM) have pointed to the role of carbon particles as nucleation seeds in the formation of atmospheric aerosols. However, the underlying physicochemical mechanisms remain unclear, particularly concerning the involvement of volatile organic compounds (VOCs) at the primary stage of clustering. Here we gain insights into those microscopic formation mechanisms through molecular dynamics simulations of the physisorption of gaseous organic molecules on the surface of a carbon nanoparticle (NP). Six different organic species are selected among the VOCs dominating the atmospheric pollutants of several megacities, to interact with an onion-shell nanostructure that mimics the primary soot particle. We consider organic molecules at various densities on the surface of a NP, as well as the same molecules in the gas phase without any NP.

The pollutant molecules are found to cluster in clearly different ways in the presence of the NP than in the gas phase. The contrast in the binding energy of molecular clusters confirms the catalytic role of black carbon in the primary formation of aerosols from VOCs. Morphology analysis reveals different clustering behaviors of aromatic and aliphatic compounds, leading to differences in the thermal stability of the formed PMs. Our simulations also suggest a layer-by-layer formation process of aerosol PM, consistent with the onion-like nanostructures of aerosol particles previously observed in transmission electron microscopy experiments. These results shed light on the microscopic mechanisms of primary aerosol formation, and are correlated with a variety of experimental measurements on aerosol PMs and VOCs.

Copyright statement. This work is distributed under the Creative Commons Attribution 3.0 License.

\section{Introduction}

Atmospheric aerosol particulate matter (PM) takes part in many environmental processes that impact climate and health, so its formation has been the object of intensive research efforts. Volatile organic compounds (VOCs) emitted into the atmosphere 
from diverse environmental sources have been reported to act as precursors of organic aerosols (Hallquist et al., 2009; Tao et al., 2017; Volkamer et al., 2009; Carlton et al., 2009; Ziemann and Atkinson, 2012; Gentner et al., 2017; Hettiyadura et al., 2019; Majdi et al., 2019; Li et al., 2019; Lim et al., 2019; Maclean et al., 2017). Numerical simulations have been carried out at the molecular level to gain insights into the morphology of aerosols and the energetics of their nucleation from VOCs (Chakraborty and Zachariah, 2011; Li et al., 2010; Ma et al., 2011; Zhao et al., 2019; Hede et al., 2011). Notably, molecular dynamics (MD) simulations have been used to study the morphology and clustering of organic and inorganic compound under atmospherically relevant conditions (Li et al., 2010; Darvas et al., 2011; Ma et al., 2011; Darvas et al., 2013; Radola et al., 2017; Karadima et al., 2019).

Many studies on the mixing state of aerosol PM have pointed to a role of black carbon (BC) as nucleation seeds for the formation of aerosol PM (Adachi et al., 2010; Bondy et al., 2018; Chen et al., 2017; Metcalf et al., 2013; Niemi et al., 2006; Li et al., 2011, 2015; Fu et al., 2012; Zhang et al., 2015; Riemer et al., 2019). BC is usually formed by incomplete combustion of fuels and biomass, and is often found in soot particles (Dallmann et al., 2014; Nienow and Roberts, 2006). It is abundantly present in the atmosphere of modern cities, especially in mega-cities in northern China due to coal burning and vehicle emission (Han et al., 2010; Rose et al., 2011; Cheng et al., 2012; Almanza et al., 2012; Wang et al., 2016; Ueda et al., 2018). Many experimental efforts have been devoted to understand the role of BC in the formation of aerosol PM and to study its impact on the visibility reduction and climate change (Koch et al., 2011; Ueda et al., 2016; Forestieri et al., 2018; Mahrt et al., 2018; Yu et al., 2019; Lefevre et al., 2019). There is therefore clear interest in characterizing the currently unclear physicochemical processes at the root of aerosol formation, particularly the primary stage of molecular clustering involving the interaction between BC and VOCs.

Here we use MD simulations to study the physisorption of gaseous organic compounds on BC nanoparticles, which is correlated to the primary formation process of aerosol PM from VOCs. The binding energy and morphology of the molecular clusters obtained from molecular simulations are analyzed as a way to gain insight into the role of BC in the primary growth of organic aerosols. The molecular clusters formed on the NP are found to be energetically mores table than those formed in the gas phase, which points to a catalytic role of black carbon in the primary formation of aerosols from VOCs. Furthermore, morphology analysis reveals different values of the binding energy and thus different thermal stability of aromatic and aliphatic compounds can be related to different ways of clustering.

\section{Methods}

Primary soot particles of BC have often observed to exhibit sub-micron fullerene-like onion-shell structures in experiments using laser desorption mass spectrometry (LDMS) and transmission electron microscopy (TEM) (Li et al., 2003; Wentzel et al., 2003; Nienow and Roberts, 2006). To mimic those reported structures, the carbon nanoparticle (NP) in this work is modeled as a bucky-onion of $3.64 \mathrm{~nm}$ in diameter containing four concentric fullerene layers (Langlet et al., 2007). The system size is kept small due to computational cost considerations, even though BC particles in urban atmospheres can grow from tens to over a 


$$
\varepsilon=\frac{\varepsilon^{\text {total }}-\left(\varepsilon^{\mathrm{np}}+\sum_{i=1}^{N} \varepsilon_{i}^{\mathrm{a}}\right)}{N},
$$

hundred nanometers after mixing with other compounds through atmospheric aging processes (Rose et al., 2006; Adachi and Buseck, 2008; Lee et al., 2015; Pei et al., 2018).

VOCs emitted from both biogenic and anthropogenic sources often dominate the atmospheric pollution in megacities (Barletta et al., 2005; Da Silva et al., 2018; Hsieh and Tsai, 2002; An et al., 2011; Ras et al., 2009; Molteni et al., 2018; Cao et al., 2018; Yang et al., 2018). Here we select six representative carbohydrates from VOCs reported by these previous works as adsorbates, because of their elemental but diverse structures. These samples include ethylene, propylene, toluene, styrene, ethylbenzene and para-xylene, all shown in Fig. 1 (a).

The atomistic interactions are described in the framework of the adaptive interatomic reactive empirical bond order (AIREBO) potential, in which the total energy is built from individual bond contributions involving many-body terms. The long-range van der Waals (vdW) interactions are included by adding a parametrized Lennard-Jones (LJ) function with a cutoff radius of $1.0 \mathrm{~nm}$. Details concerning the formulation, parameterization and benchmarks of the AIREBO potential are provided elsewhere (Stuart et al., 2000). This force field has recently shown good accuracy in describing the deformation and adsorption behaviors of carbon nanostructures (Wang, 2009; Wang and Philippe, 2009; Petucci et al., 2013; Sun and Bai, 2017).

Like in our earlier works (Wang and Devel, 2011; Wang, 2019a), the adsorption process is simulated by integrating the equations of motion of all atoms in the system using the parallel MD package Lammps (Plimpton, 1995). Organic molecules are initially placed at random sites near the surface of NP in a periodic simulation cell of about $10 \times 10 \times 10 \mathrm{~nm}{ }^{3}$, as shown in Fig. 1 (b). Initial velocities are sampled from a Maxwell-Boltzmann distribution. A thermostat is then used to let the NP progressively reach thermal equilibrium at $300 \mathrm{~K}$ in about $0.5 \mathrm{~ns}$, during which most of the molecules interact with the NP surface; this interval was determined to be enough after testing with the case of toluene as a reference. The case without NP is also simulated under the same conditions for a purpose of comparison, as illustrated in Fig. 1 (c). In this case, the thermostat is applied directly to the molecules instead.

A repeated heating-annealing process is used to compute the statistical energy of atomization of the system. Energy minimization is performed via an annealing process after reaching thermal equilibrium, in order to take a "frozen" picture of the system, from which the energy is calculated. After optimization, the temperature is raised again and molecules are free to move at $300 \mathrm{~K}$. This heating-annealing process is repeated for 13 times (determined after a convergence test) in each case to let the system hop among metastable states and compute an average. The full set of Lammps inputs required to replicate these simulations is provided with the online version.

A key coefficient influencing the clustering of molecules, the per-molecule binding energy $\varepsilon$ is calculated as the difference in the energy of atomization between the whole system and the sum of that of the NP and clustering adsorbates that are isolated from each other, divided by $N$, the total number of organic molecules in the simulation cell:

where $\varepsilon^{\mathrm{np}}$ is zero for the case without NP. 


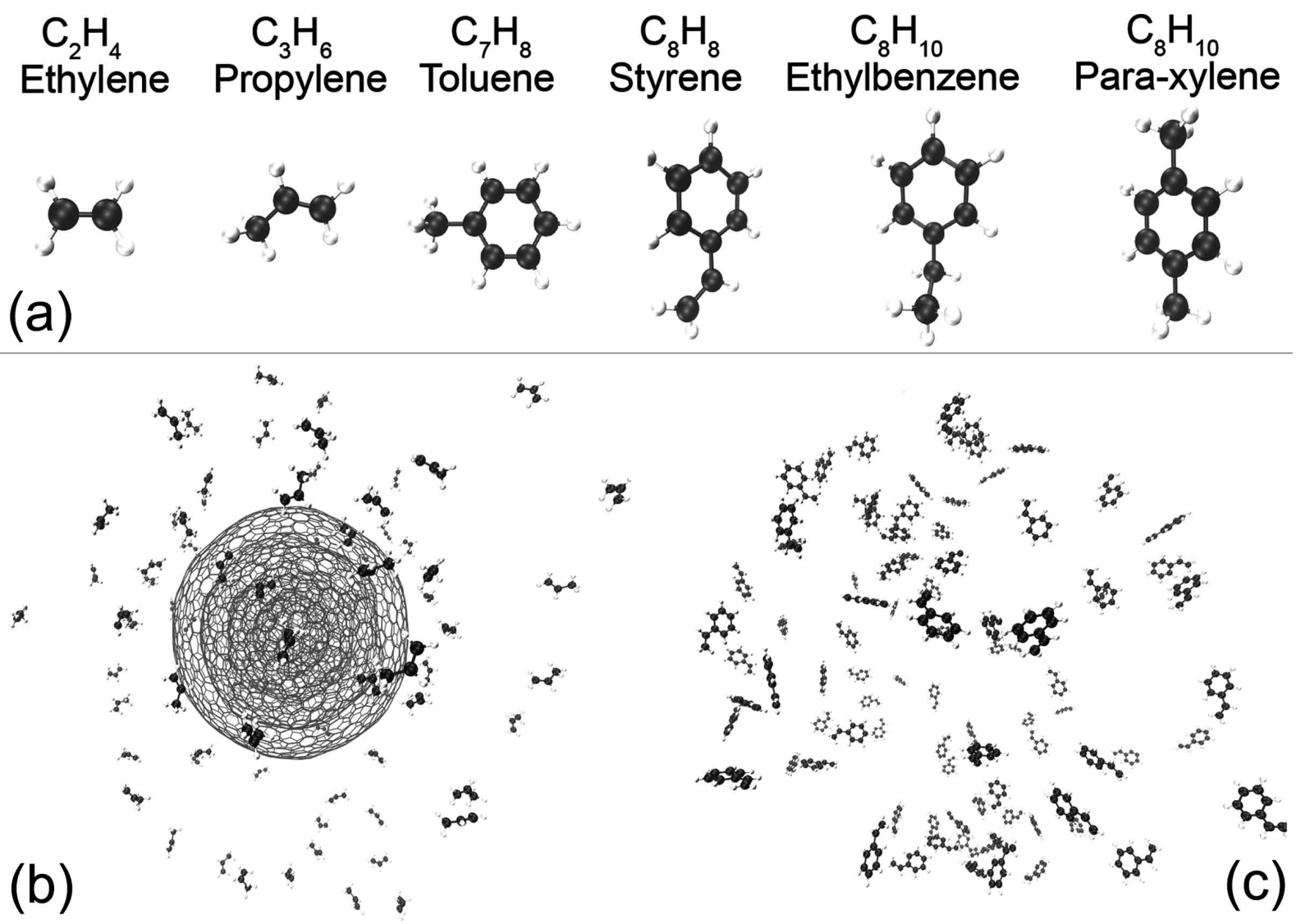

Figure 1. (a) Ball-and-stick model of the organic compounds studied in this work. Carbon atoms are depicted in black, hydrogens in gray. (b) and (c) Snapshots of the initial simulation cells for 90 propylene molecules around a $3.64 \mathrm{~nm}$ diameter NP, and 90 ethylbenzene molecules without any NP, respectively. This cell is periodic in all three orthogonal directions.

\section{Results and discussion}

Fig. 2 shows the per-molecule binding energy $\varepsilon$ as a function of the number of molecules $N$ with (a), and without (b) a NP in the simulation box. Comparing the two panels, we see that the absolute values of $\varepsilon$ are in general much higher for the case with NP. This means that more energetically-stable clusters can form in presence of the NP which provides a physical substrate of adsorption. Hence, this points to a possible catalytic role of carbon NP in the formation of molecular aggregates. The physisorption of organic compounds could be an important primary stage in the formation of aerosols.

Indeed, positive correlations between the concentrations of aerosol PM and BC have recently been reported by measurements across different continents (Hyvarinen et al., 2011; Marinoni et al., 2010; Ripoll et al., 2014; Rupakheti et al., 2017; Sarkar et al., 2019; Schaap et al., 2004). For instance, a study in a number of European cities has shown that the PM and BC concentrations exhibit similar daily cycles, with a few exceptions caused by secondary formation of particles by means 


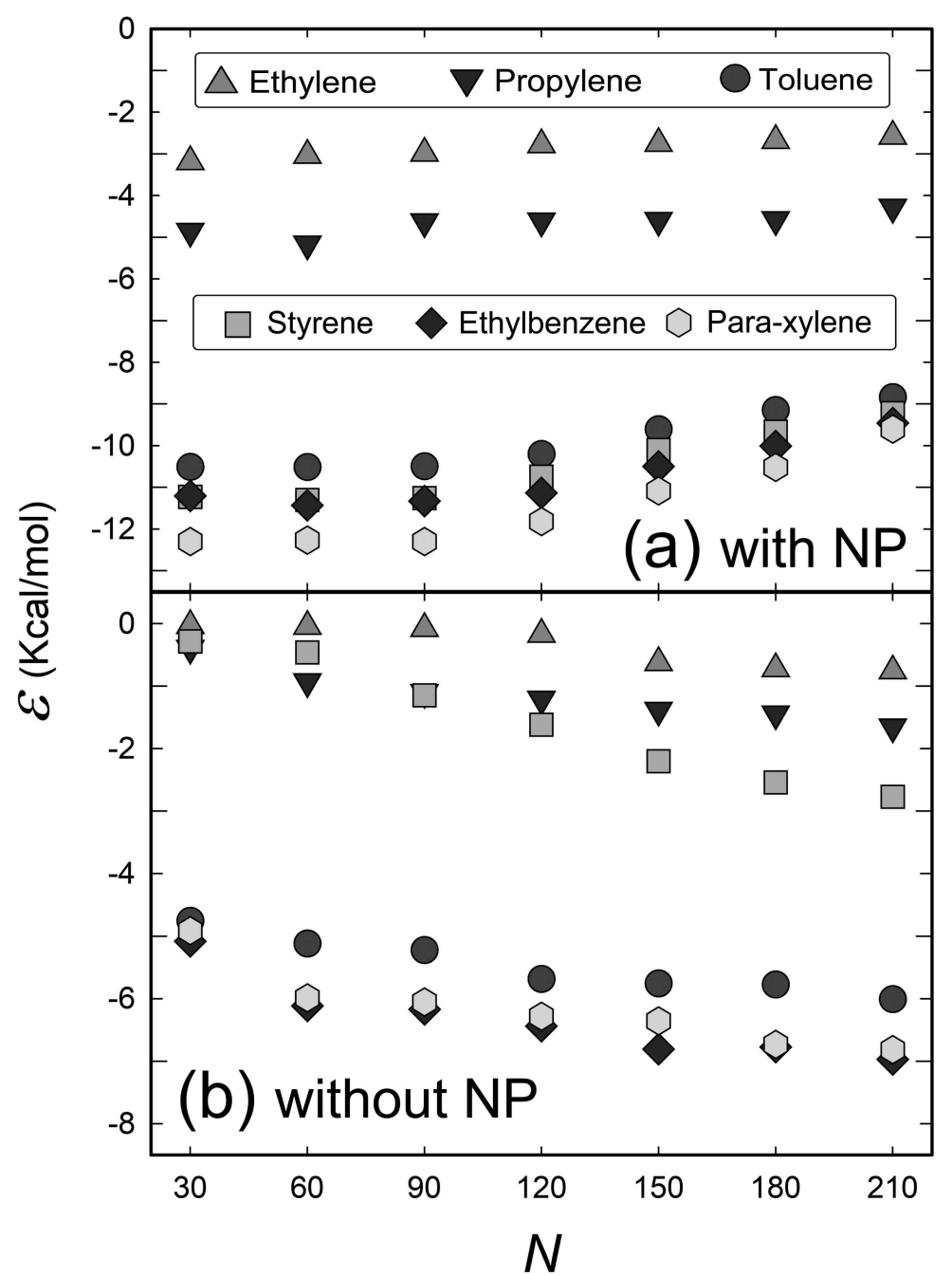

Figure 2. Per-molecule binding energy vs. number of molecules for different molecular species (a) physisorbed on the NP surface, or (b) without NP. 
of photochemical nucleation processes from gaseous precursors (Reche et al., 2011). Strong correlations between $\mathrm{PM}_{2.5}$ mass and BC concentration have also been observed at urban sites in Korea (Park and Kim, 2004), India (Arif et al., 2018; Marrapu et al., 2014), New Zealand (Trompetter et al., 2013) and China (Shen et al., 2015; Liu et al., 2019).

\section{(a) Toluene with NP}
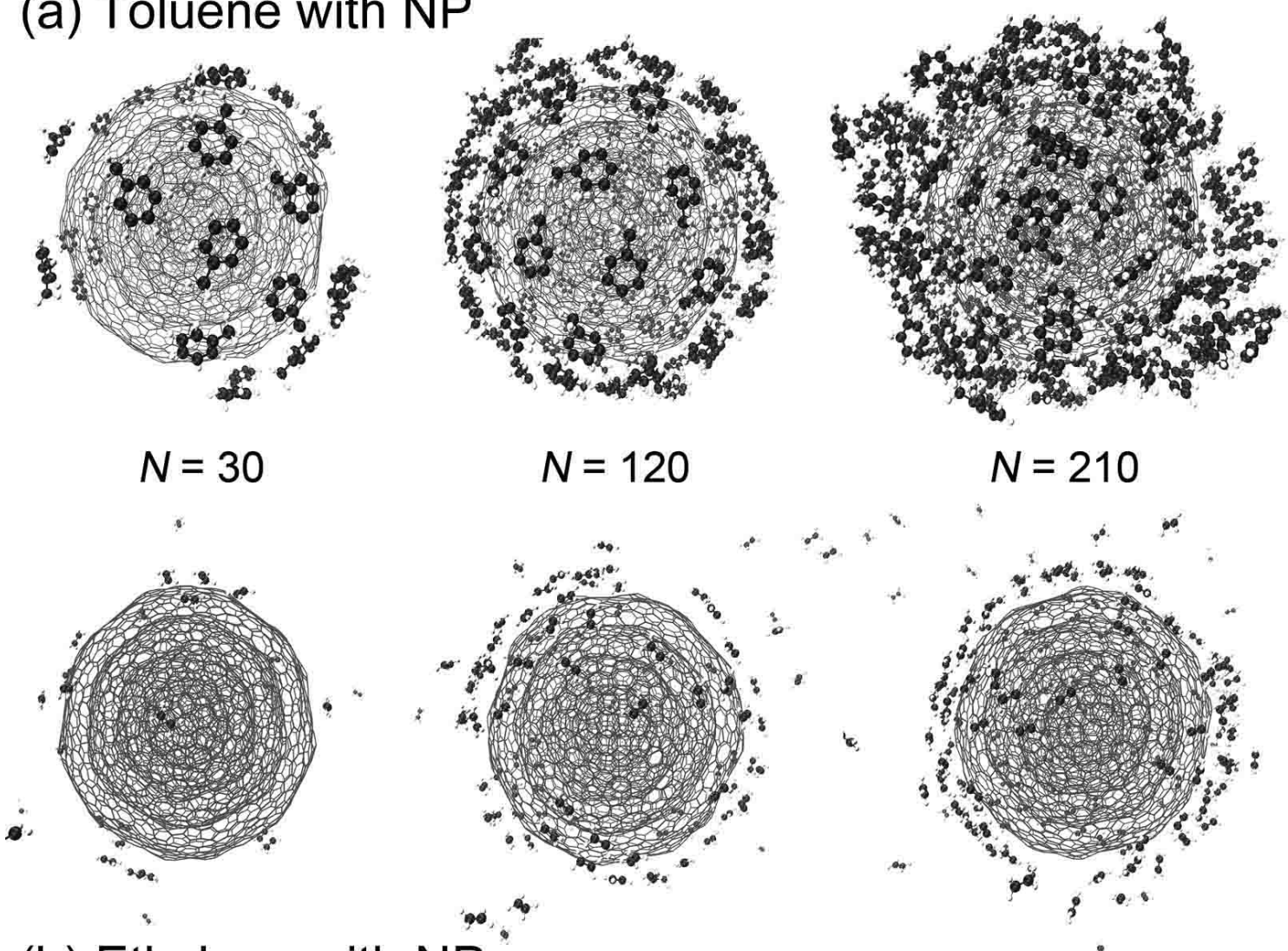

(b) Ethylene with NP

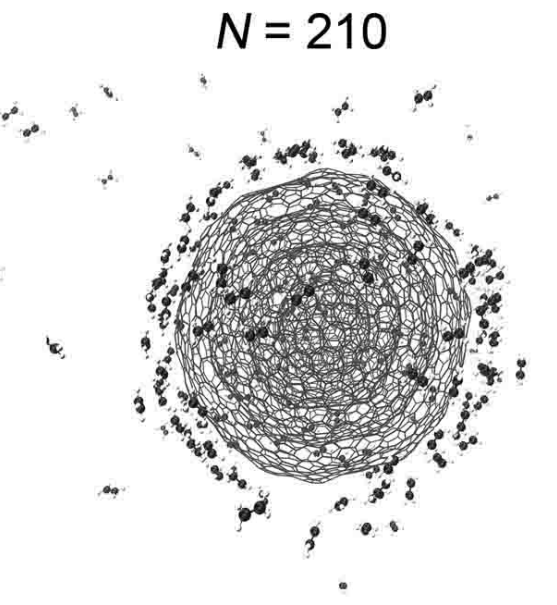

Figure 3. Atomistic configurations of different numbers of (a) toluene and (b) ethylene molecules on a NP.

In Fig. 2 (a), the four aromatic compounds (para-xylene, ethylbenzene, styrene and toluene) have clearly higher absolute values of $\varepsilon$ than the two aliphatic compounds. This is not only due to different numbers of atoms in the molecule, but also due to the difference in the NP surface coverage. Examining the morphology of the formed clusters, we find that most of the aromatic molecules aggregate on the surface of NP more readily than the aliphatic ones, as shown in Fig. 3 as examples. For instance, the right panels $(N=210)$ shows that the toluene molecules start to form three-dimensional (3D) aggregates, while the ethylene ones form only a thin monolayer with many molecules being isolated in the gas phase. The clusters formed in the simulations are provided in supplementary data files that contain optimized molecular configurations.

As a general trend, in each simulation, molecules are first observed forming a single thin layer over the NP surface instead of stacking up in 3D, suggesting a layer-by-layer growth mechanism that is supported by the two slopes of the $\varepsilon$ curves shown 
https://doi.org/10.5194/acp-2020-81

Preprint. Discussion started: 20 February 2020

(c) Author(s) 2020. CC BY 4.0 License.

(c) (i)

in Fig. 2 (a) (as discussed below). This layer-by-layer growth mechanism could be a general process for aerosol aging in the atmosphere, since it is consistent with TEM observations of BC embedded within host organic matters in aerosol PM collected from regions across different continents (Adachi et al., 2010; Katrinak et al., 1993; Li et al., 2003). This clustering process is clearly illustrated in the animations provided as video supplements.

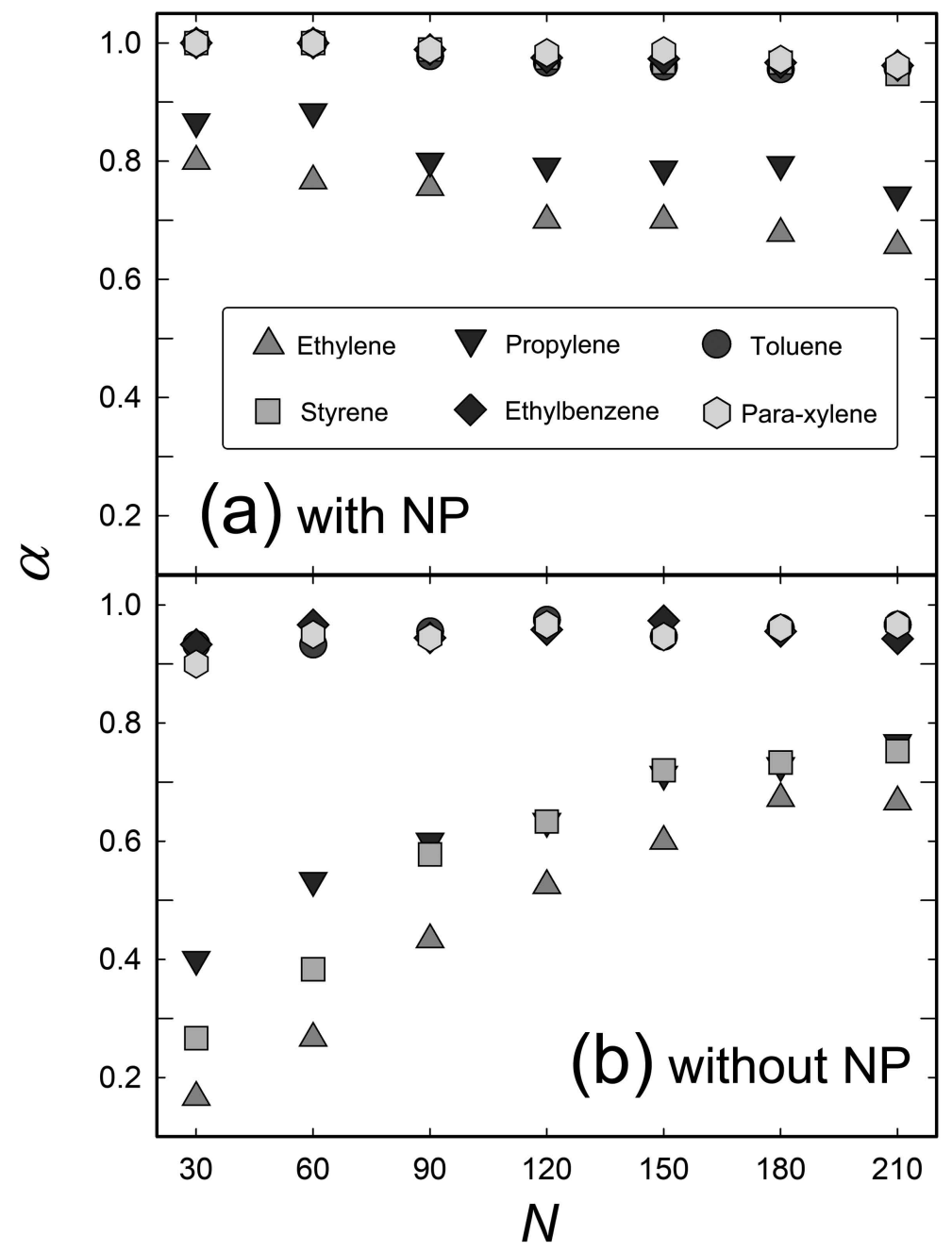

Figure 4. Molecular aggregation factor $\alpha$ vs. number of molecules of different molecular species (a) physically adsorbed on the NP surface, or (b) without any NP. $\alpha$ is averaged over thirteen different metastable states.

111 To quantify how the case shown in Fig. 3 is a general situation in the simulation results, we compute a molecular aggregation 112 factor for all simulations, which is defined as

$113 \alpha=\frac{N-N_{\text {iso }}}{N}$, 
where $N_{\text {iso }}$ is the number of isolated molecules suspended in the gas phase, as defined by a cutoff radius of $1.0 \mathrm{~nm}$ consistent with the one used in the AIREBO function. $\alpha$ reaches its maximum 1.0 when all molecules in the simulation box cluster together and form a single particle. More generally, the higher $\alpha$ is, the larger the molecular aggregates formed in the simulation box are. In Fig. 4 we plot the values of $\alpha$ as a function of the total number of molecules for different molecular species. A clear positive correlation is seen between $\alpha$ and the absolute values of $\varepsilon$ shown in Fig. 2. For instance, $\alpha$ values for ethylene, propylene and styrene are much higher in the presence of the NP than without it, as shown on Fig. 4, and the same trend is observed in the corresponding values of $\varepsilon$ shown in Fig. 2.

Fig. 4 also shows a difference in the clustering behaviors of aromatic and aliphatic compounds, which leads to different values of $\varepsilon$ shown in Fig. 2. This difference could come from the particular stacking order of $s p^{2}$ hybridized carbons, i.e., the so-called $\pi-\pi$ stacking. Indeed, it is more energetically favorable for an aromatic molecule to be stacked parallel to the NP surface (Bjork et al., 2010). Hence, the planar structures of aromatic molecules help when forming thermally stable aggregates on the NP surface. This is consistent with previous results about the selective conduction of organic molecules on the surface of graphene (Wang, 2019b).

When additional aromatic molecules come to the NP surface after the first thin layer is formed, those molecules are observed to form $\pi-\pi$ stacks on top of each other and therefore form a core-shell nanostructure. Note that this $\pi-\pi$ stacking occurs also without NP in the simulation box, as can be seen in Figs. 5 (b) and (c). This selectivity of adsorption suggests that molecules with planar structures could form more stable and larger aggregates when interacting with BC in atmosphere. This is in keeping with previously reported correlations between the concentrations of aromatic compounds and aerosol PM, notably those of polycyclic aromatic hydrocarbons (PAHs) which could have been formed from small aromatic molecules (Haritash and Kaushik, 2009; Mu et al., 2017; Lyu et al., 2019; Richter and Howard, 2000; Marr et al., 2006; Elzein et al., 2019; Lv et al., 2016; Polidori et al., 2008).

When there is no NP in the simulation box, the $|\varepsilon|$ for aromatic compounds is also generally higher than for aliphatic ones as shown in Fig. 2 (b). This difference is consistent with their different clustering behaviors, as evidenced in Fig. 4 (b). Propylene and ethylbenzene are taken as examples in Figs. 5 (a) and (b) for comparison. Thus, it seems that propylene molecules form only a few small aggregates, whereas the clusters of ethylbenzene molecules are much larger at the same number density.

An exception, styrene, has much lower values of $|\varepsilon|$ [Fig. 2 (b)] and $\alpha$ [Fig. 4 (b)] in gas phase than other aromatic compounds of similar molecular structures. Indeed, it is found to be much harder for styrene molecules to form aggregates in the gas phase than for the three other aromatic species, as shown in Fig. 5 (c). Although the underlying reason for this behavior remains unclear, we assume that this may come from the $s p^{2}$-type hybridization of the benzene and the vinyl groups of styrene, so that both prefer a planar stacking order (Bjork et al., 2010; Kolmogorov and Crespi, 2005). A "comfortable" configuration might not easily be achieved in gas phase when the styrene molecules are bent due to interaction with their neighbors in the clusters, evidenced by the fact that the binding energy of styrene is comparable to that of other aromatic compounds with NP as shown in Fig. 2 (a). By contrast, the $s p^{3}$ hybridized methyl and ethyl groups in the three other aromatic compounds have more isotropic stacking orders. 


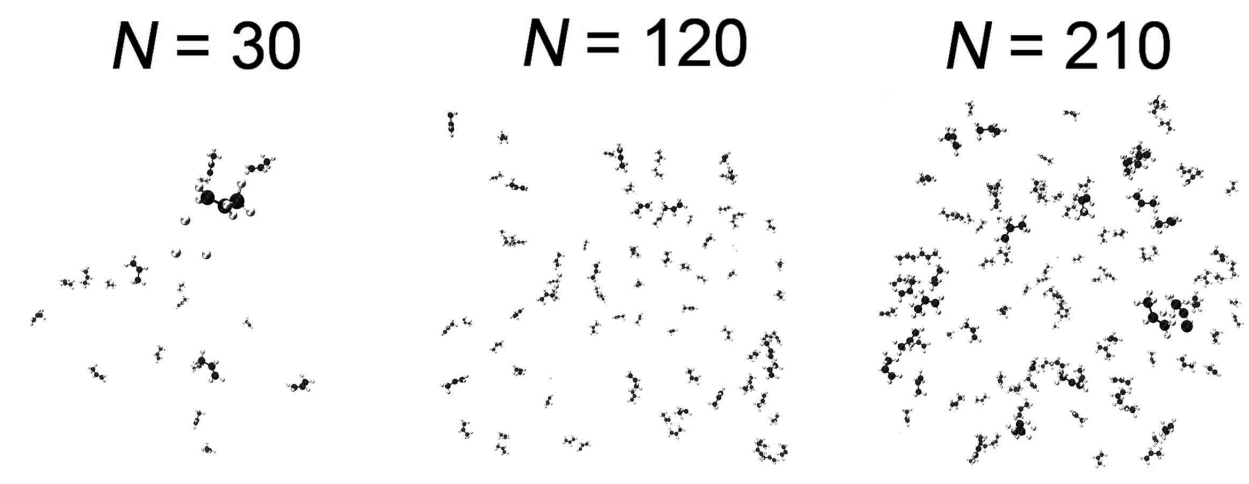

\section{(a) Propylene without NP}
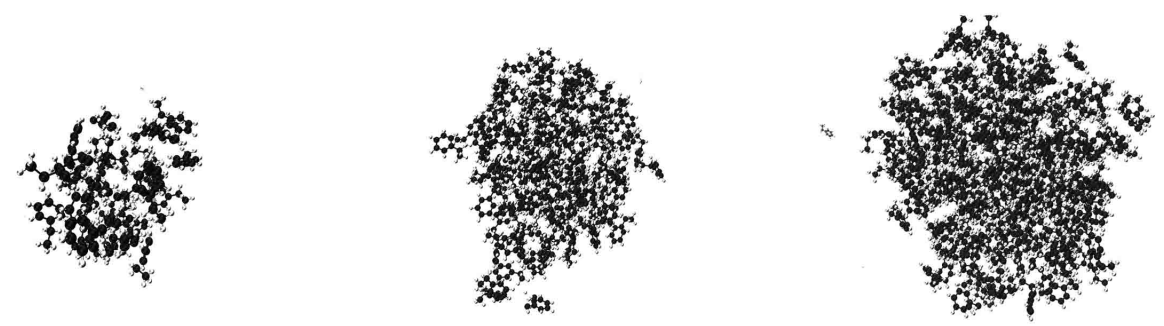

\section{(b) Ethylbenzene without NP}
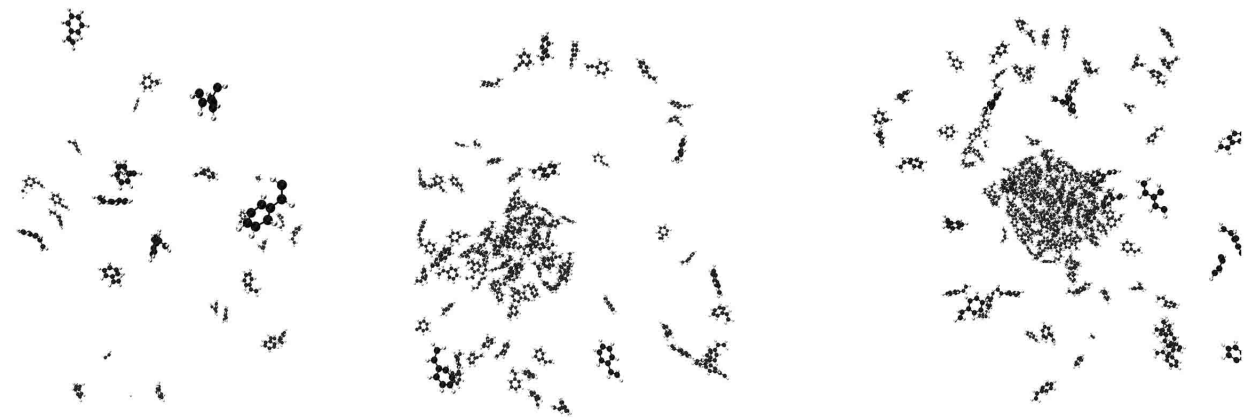

\section{(c) Styrene without NP}

Figure 5. Atomistic configurations of different numbers of (a) propylene, (b) ethylbenzene and (b) styrene molecules without any NP. 
The physisorption of six organic compounds on the surface of a carbon NP is simulated in order to mimic the primary formation stage of aerosols with VOC precursors. The results of our binding energy calculations show that more stable clusters can form thanks to the presence of the NP, and thus point to a catalytic role of BC in the formation of aerosol PM. This could be useful for understanding the correlation between experimentally-measured concentrations of aerosol PM and BC. It is also found that the absolute binding energy of the aromatic compounds is different from that of aliphatic ones, due to the large difference in their clustering behaviors. This could be related to previously-reported correlation between the concentrations of aromatic compounds and aerosol PM, in particular PAHs. Furthermore, analysis on the morphology of the resulting particles points to a layer-by-layer formation process of aerosol PM in atmospheric aging, in agreement with experimental observations of BC embedded within host organic matters in aerosol PM. repeat the simulations.

Data availability. Data files that contain optimized atomistic configurations of organic molecules adsorbed on nanoparticles are provided via https://dx.doi.org/10.5281/zenodo.3628331. These .xyz files contain the atomic coordinates of the adsorbed organic molecules. The first line in each file contains the total number of atoms, the second line comprises three integers corresponding to the number of molecules, number of atoms in each molecule and number of atoms in the nanoparticle, and each subsequent line contains the atomic species and the three Cartesian coordinates (in $\AA$ ) for an atom. Please see the PDF in the zipped file for instructions.

Video supplement. Video supplements are available via https://dx.doi.org/10.5281/zenodo.3628331 for demonstrating the formation process of molecular clusters.

Author contributions. Z. W. conceived and designed the simulations. X. Z. performed the simulations and collected the data. Z. W., X. Z., Y. Z., S.P. and M. D. contributed data analysis. Z. W., Y. Z., S. P., M. D., J. C. and G. M. wrote the paper.

Competing interests. The authors declare no competing interest. 
https://doi.org/10.5194/acp-2020-81

Preprint. Discussion started: 20 February 2020

(C) Author(s) 2020. CC BY 4.0 License.

(c) (1)

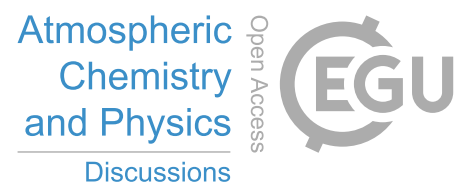

170 Acknowledgements. Peter Blaha and Karlheinz Schwarz are acknowledged for helpful discussions. Partial financial supports from the Na-

171 tional Natural Science Foundation of China (11964002), the Guangxi Science Foundation (2018GXNSFAA138179) and the Scientific Re-

172 search Foundation of Guangxi University (XTZ160532) are acknowledged. 


\section{References}

Adachi, K. and Buseck, P. R.: Internally mixed soot, sulfates, and organic matter in aerosol particles from Mexico City, Atmos. Chem. Phys., $8,6469,2008$.

Adachi, K., Chung, S. H., and Buseck, P. R.: Shapes of soot aerosol particles and implications for their effects on climate, J. Geophys. Res., 115, D15 206, 2010.

Almanza, V. H., Molina, L. T., and Sosa, G.: Soot and $\mathrm{SO}_{2}$ contribution to the supersites in the MILAGRO campaign from elevated flares in the Tula Refinery, Atmos. Chem. Phys., 12, $10583,2012$.

An, J. L., Wang, Y. S. Wu, F. K., and Zhu, B.: Characterizations of volatile organic compounds during high ozone episodes in Beijing, China, Environ. Monit. Assess., 184, 1879, 2011.

Arif, M., Kumar, R., Kumar, R., Eric, Z., and Gourav, P.: Ambient black carbon, $\mathrm{PM}_{2.5}$ and $\mathrm{PM}_{10}$ at Patna: Influence of anthropogenic emissions and brick kilns, Sci. Total Environ., 624, 1387, 2018.

Barletta, B., Meinardi, S., Rowland, F. S., Chan, C. Y., Wang, X., Zou, S., Chan, L. Y., and Blake, D. R.: Volatile organic compounds in 43 Chinese cities, Atmos. Environ., 39, 5979, 2005.

Bjork, J., Hanke, F., Palma, C. A., Samori, P., Cecchini, M., and Persson, M.: Adsorption of aromatic and anti-aromatic systems on graphene through $\pi-\pi$ stacking, J. Phys. Chem. Lett., 23, 3407, 2010.

Bondy, A. L., Bonanno, D., Moffet, R. C., Wang, B. B., Laskin, A., and Ault, A. P.: The diverse chemical mixing state of aerosol particles in the southeastern United States, Atmos. Chem. Phys., 18, 12 595, 2018.

Cao, H. S., Fu, T. M., Zhang, L., Henze, D. K., Miller, C. C., Lerot, C., Abad, G. G., De Smedt, I., Zhang, Q., van Roozendael, M., Hendrick, F., Chance, K., Li, J., Zheng, J. Y., and Zhao, Y. H.: Adjoint inversion of Chinese non-methane volatile organic compound emissions using space-based observations of formaldehyde and glyoxal, Atmos. Chem. Phys., 18, 15 017, 2018.

Carlton, A. G., Wiedinmyer, C., and Kroll, J. H.: A review of Secondary Organic Aerosol (SOA) formation from isoprene, Atmos. Chem. Phys., 9, 4987, 2009.

Chakraborty, P. and Zachariah, M. R.: On the structure of organic-coated water droplets: From "net water attractors" to "oily" drops, J. Geophys. Res., 116, D21 205, 2011.

Chen, S. R., Xu, L., Zhang, Y. X., Chen, B., Wang, X. F., Zhang, X. Y., Zheng, M., Chen, J. M., Wang, W. X., Sun, Y. L., Fu, P. Q., Wang, Z. F., and Li, W. J.: Direct observations of organic aerosols in common wintertime hazes in North China: insights into direct emissions from Chinese residential stoves, Atmos. Chem. Phys., 17, 1258, 2017.

Cheng, Y. F., Su, H., Rose, D., Gunthe, S. S., Berghof, M., Wehner, B., Achtert, P., Nowak, A., Takegawa, N., Kondo, Y., Shiraiwa, M., Gong, Y. G., Shao, M., Hu, M., Zhu, T., Zhang, Y. H., Carmichael, G. R., Wiedensohler, A., Andreae, M. O., and Poschl, U.: Size-resolved measurement of the mixing state of soot in the megacity Beijing, China: diurnal cycle, aging and parameterization, Atmos. Chem. Phys., $12,4477,2012$.

Da Silva, C. M., Da Silva, L. L., Correa, S. M., and Arbilla, G.: A minimum set of ozone precursor volatile organic compounds in an urban environment, Atmos. Pollut. Res., 9, 369, 2018.

Dallmann, T. R., Onasch, T. B. Kirchstetter, T. W., Worton, D. R., Fortner, E. C., Herndon, S. C. Wood, E. C., Franklin, J. P., Worsnop, D. R., Goldstein, A. H., and Harley, R. A.: Characterization of particulate matter emissions from on-road gasoline and diesel vehicles using a soot particle aerosol mass spectrometer, Atmos. Chem. Phys., 14, 7585, 2014. 
Darvas, M., Picaud, S., and Jedlovszky, P.: Water Adsorption Around Oxalic Acid Aggregates : A Molecular Dynamics Simulation of Water Nucleation on Organic Aerosols, Phys. Chem. Chem. Phys., 13, 19 830-19 839, 2011.

Darvas, M., Picaud, S., and Jedlovszky, P.: Molecular Dynamics Simulations of the Water Adsorption Around Malonic Acid Aerosol Models, Phys. Chem. Chem. Phys., 15, 10942-10 951, 2013.

Elzein, A., Dunmore, R. E., Ward, M. W., Hamilton, J. F., and Lewis, A. C.: Variability of polycyclic aromatic hydrocarbons and their oxidative derivatives in wintertime Beijing, China, Atmos. Chem. Phys., 19, 8741, 2019.

Forestieri, S. D., Helgestad, T. M., Lambe, A. T., Renbaum-Wolff, L., Lack, D. A., Massoli, P., Cross, E. S., Dubey, M. K., Mazzoleni, C. Olfert, J. S., Sedlacek, A. J., Freedman, A., Davidovits, P., Onasch, T. B., and Cappa, C. D.: Measurement and modeling of the multiwavelength optical properties of uncoated flame-generated soot, Atmos. Chem. Phys., 18, 12 141, 2018.

Fu, H., Zhang, M., Li, W., Chen, J., Wang, L., Quan, X., and Wang, W.: Morphology, composition and mixing state of individual carbonaceous aerosol in urban Shanghai, Atmos. Chem. Phys., 12, 693, 2012.

Gentner, D. R., Jathar, S. H., Gordon, T. D., Bahreini, R., Day, D. A., El Haddad, I., Hayes, P. L., Pieber, S. M., Platt, S. M., de Gouw, J., Goldstein, A. H., Harley, R. A., Jimenez, J. L., Prevot, A. S. H., and Robinson, A. L.: Review of Urban Secondary Organic Aerosol Formation from Gasoline and Diesel Motor Vehicle Emissions, Environ. Sci. Technol., 51, 1074, 2017.

Hallquist, M., Wenger, J. C., Baltensperger, U., Rudich, Y., Simpson, D., Claeys, M., Dommen, J., Donahue, N. M., George, C., Goldstein, A. H., Hamilton, J. F., Herrmann, H., Hoffmann, T., Iinuma, Y., Jang, M., Jenkin, M. E., Jimenez, J. L., Kiendler-Scharr, A., Maenhaut, W., McFiggans, G., Mentel, T. F., Monod, A., Prevot, A. S. H., Seinfeld, J. H., Surratt, J. D., Szmigielski, R., and Wildt, J.: The formation, properties and impact of secondary organic aerosol: current and emerging issues, Atmos. Chem. Phys., 9, 5155, 2009.

Han, Y. M., Cao, J. J., Lee, S. C., Ho, K. F., and An, Z. S.: Different characteristics of char and soot in the atmosphere and their ratio as an indicator for source identification in Xi'an, China, Atmos. Chem. Phys., 10, 595, 2010.

Haritash, A. K. and Kaushik, C. P.: Biodegradation aspects of Polycyclic Aromatic Hydrocarbons (PAHs): A review, J. Hazard. Mater., 169, $1,2009$.

Hede, T., Li, X., Leck, C., Tu, Y., and Agren, H.: Model HULIS compounds in nanoaerosol clusters-investigations of surface tension and aggregate formation using molecular dynamics simulations, Atmos. Chem. Phys., 11, 6549, 2011.

Hettiyadura, A. P. S., Al-Naiema, I. M., Hughes, D. D., Fang, T., and Stone, E. A.: Organosulfates in Atlanta, Georgia: anthropogenic influences on biogenic secondary organic aerosol formation, Atmos. Chem. Phys., 19, 3191, 2019.

Hsieh, C. C. and Tsai, J. H.: VOC concentration characteristics in Southern Taiwan, Chemosphere, 50, 545, 2002.

Hyvarinen, A. P., Raatikainen, T., Brus, D., Komppula, M., Panwar, T. S., Hooda, R. K., Sharma, V. P., and Lihavainen, H.: Effect of the summer monsoon on aerosols at two measurement stations in Northern India - Part 1: PM and BC concentrations, Atmos. Chem. Phys., $11,16,2011$.

Karadima, K. S., Mavrantzas, V. G., and Pandis, S. N.: Insights into the morphology of multicomponent organic and inorganic aerosols from molecular dynamics simulations, Atmos. Chem. Phys., 19, 5571, 2019.

Katrinak, K. A., Rez, P., Perkes, P. R., and Buseck, P. R.: Fractal geometry of carbonaceous aggregates from an urban aerosol, Environ. Sci. Technol., 27, 539, 1993.

Koch, D., Balkanski, Y., Bauer, S. E., Easter, R. C., Ferrachat, S., Ghan, S. J., Hoose, C., Iversen, T., Kirkevag, A., Kristjansson, J. E., Liu, X., Lohmann, U., Menon, S., Quaas, J., Schulz, M., Seland, O., Takemura, T., and Yan, N.: Soot microphysical effects on liquid clouds, a multi-model investigation, Atmos. Chem. Phys., 11, 1051, 2011.

Kolmogorov, A. N. and Crespi, V. H.: Registry-dependent interlayer potential for graphitic systems, Phys. Rev. B, 71, $235415,2005$. 
Langlet, R., Mayer, A., Geuquet, N., Amara, H., Vandescuren, M., Henrard, L., Maksimenko, S., and Lambin, P.: Study of the polarizability of fullerenes with a monopole-dipole interaction model, Diamond Relat. Mater., 16, 2145, 2007.

Lee, A. K. Y., Willis, M. D., Healy, R. M., Onasch, T. B., and Abbatt, J. P. D.: Mixing state of carbonaceous aerosol in an urban environment: single particle characterization using the soot particle aerosol mass spectrometer (SP-AMS), Atmos. Chem. Phys., 15, $1823,2015$.

Lefevre, G., Yon, J., Bouvier, M., Liu, F., and Coppalle, A.: Impact of organic coating on soot angular and spectral scattering properties, Environ. Sci. Technol., 53, 6383, 2019.

Li, J., Posfai, M., Hobbs, P. V., and Buseck, P. R.: Individual aerosol particles from biomass burning in southern Africa: 2. Compositions and aging of inorganic particles, J. Geophys. Res., 108, 8484, 2003.

Li, K., Liggio, J., Lee, P., Han, C., Liu, Q. F., and Li, S. M.: Secondary organic aerosol formation from $\alpha$-pinene, alkanes, and oil-sandsrelated precursors in a new oxidation flow reactor, Atmos. Chem. Phys., 19, 9715, 2019.

Li, W. J., Zhang, D. Z., Shao, L. Y., Zhou, S. Z., and Wang, W. X.: Individual particle analysis of aerosols collected under haze and non-haze conditions at a high-elevation mountain site in the North China plain, Atmos. Chem. Phys., 11, 11 733, 2011.

Li, W. J., Chen, S., Xu, Y. S., Guo, X., Sun, Y. L., Yang, X. Y., Wang, Z. F., Zhao, X. D., Chen, J. M., and Wang, W. X.: Mixing state and sources of submicron regional background aerosols in the northern Qinghai-Tibet Plateau and the influence of biomass burning, Atmos. Chem. Phys., 15, 13 365, 2015.

Li, X., Hede, T., Tu, T., Leck, C., and Agren, H.: Surface-Active cis-Pinonic Acid in Atmospheric Droplets: A Molecular Dynamics Study, J. Phys. Chem. Lett., 1, 769-773, 2010.

Lim, C. Y., Hagan, D. H., Coggon, M. M., Koss, A. R., Sekimoto, K., de Gouw, J., Warneke, C., Cappa, C. D., and Kroll, J. H.: Secondary organic aerosol formation from the laboratory oxidation of biomass burning emissions, Atmos. Chem. Phys., 19, $12797,2019$.

Liu, B., He, M. M., Wu, C., Li, J. J., Li, Y., Lau, N. T., Yu, J., Lau, A. K. H., Fung, J. C. H., Hoi, K. I., Mok, K. M., Chan, C. K., and Li, Y. J.: Potential exposure to fine particulate matter $\left(\mathrm{PM}_{2.5}\right)$ and black carbon on jogging trails in Macau, Atmos. Environ., $198,23,2019$.

Lv, Y., Li, X., Xu, T. T., Cheng, T. T. Yang, X., Chen, J. M. Iinuma, Y., and Herrmann, H.: Size distributions of polycyclic aromatic hydrocarbons in urban atmosphere: sorption mechanism and source contributions to respiratory deposition, Atmos. Chem. Phys., 16, 2971, 2016.

Lyu, R., Shi, Z., Alam, M. S., Wu, X. F., Liu, D., Vu, T. V., Stark, C., Fu, P. Q., and Feng, Y. C.: Insight into the composition of organic compounds (>= C-6) in $\mathrm{PM}_{2.5}$ in wintertime in Beijing, China, Atmos. Chem. Phys., 19, 10 865, 2019.

Ma, X. F., Chakraborty, P., Henz, B. J., and Zachariah, M. R.: Molecular dynamic simulation of dicarboxylic acid coated aqueous aerosol: structure and processing of water vapor, Phys. Chem. Chem. Phys., 13, 9374-9384, 2011.

Maclean, A. M., Butenhoff, C. L., Grayson, J. W., Barsanti, K., Jimenez, J. L., and Bertram, A. K.: Mixing times of organic molecules within secondary organic aerosol particles: a global planetary boundary layer perspective, Atmos. Chem. Phys., 17, $13037,2017$.

Mahrt, F., Marcolli, C., David, R. O., Gronquist, P., Meier, E. J. B., Lohmann, U., and Kanji, Z. A.: Ice nucleation abilities of soot particles determined with the Horizontal Ice Nucleation Chamber, Atmos. Chem. Phys., 18, 13 363, 2018.

Majdi, M., Sartelet, K., Lanzafame, G. M., Couvidat, F., Kim, Y., Chrit, M., and Turquety, S.: Precursors and formation of secondary organic aerosols from wildfires in the Euro-Mediterranean region, Atmos. Chem. Phys., 19, 5543, 2019.

Marinoni, A., Cristofanelli, P., Laj, P., Duchi, R., Calzolari, F., Decesari, S., Sellegri, K., Vuillermoz, E., Verza, G. P., Villani, P., and Bonasoni, P.: Aerosol mass and black carbon concentrations, a two year record at NCO-P (5079 m, Southern Himalayas), Atmos. Chem. Phys., 10, 8551, 2010. 
Marr, L. C., Dzepina, K., Jimenez, J. L., Reisen, F., Bethel, H. L., Arey, J., Gaffney, J. S., Marley, N. A., Molina, L. T., and Molina, M. J.: Sources and transformations of particle-bound polycyclic aromatic hydrocarbons in Mexico City, Atmos. Chem. Phys., 6, $1733,2006$.

Marrapu, P., Cheng, Y., Beig, G., Sahu, S., Srinivas, R., and Carmichael, G. R.: Air quality in Delhi during the Commonwealth Games, Atmos. Chem. Phys., 14, $10619,2014$.

Metcalf, A. R., Loza, C. L., Coggon, M. M., Craven, J. S., Jonsson, H. H., Flagan, R. C., and Seinfeld, J. H.: Secondary organic aerosol coating formation and evaporation: chamber studies using black carbon seed aerosol and the single-particle soot photometer, Aerosol Sci. Technol., 47, 326, 2013.

Molteni, U., Bianchi, F., Klein, F., El Haddad, I., Frege, C., Rossi, M. J. Dommen, J., and Baltensperger, U.: Formation of highly oxygenated organic molecules from aromatic compounds, Atmos. Chem. Phys., 18, 1909, 2018.

Mu, L., Peng, L., Liu, X. F., He, Q. S., Bai, H. L., Yan, Y. L., and Li, Y, H.: Emission characteristics and size distribution of polycyclic aromatic hydrocarbons from coke production in China, Atmos. Res., 197, 113, 2017.

Niemi, J. V., Saarikoski, S., Tervahattu, H., Makela, T., Hillamo, R., Vehkamaki, H., Sogacheva, L., and Kulmala, M.: Changes in background aerosol composition in Finland during polluted and clean periods studied by TEM/EDX individual particle analysis, Atmos. Chem. Phys., 6, 5049, 2006.

Nienow, A. M. and Roberts, J. T.: Heterogeneous chemistry of carbon aerosols, Annu. Rev. Phys. Chem., 57, $105,2006$.

Park, S. S. and Kim, Y. J.: PM $_{2.5}$ particles and size-segregated ionic species measured during fall season in three urban sites in Korea, Atmos. Environ., 38, 1459, 2004.

Pei, X. Y., Hallquist, M., Eriksson, A. C., Pagels, J., ; Donahue, N. M., Mentel, T., Svenningsson, B., Brune, W., and Pathak, R. K.: Morphological transformation of soot: investigation of microphysical processes during the condensation of sulfuric acid and limonene ozonolysis product vapors, Atmos. Chem. Phys., 18, 9845, 2018.

Petucci, J., LeBlond, C., Karimi, M., and Vidali, G.: Diffusion, adsorption, and desorption of molecular hydrogen on graphene and in graphite, J. Chem. Phys., 139, 044 706, 2013.

Plimpton, S.: Fast parallel algorithms for short-range molecular dynamics, J. Comp. Phys., 117, 1, 1995.

Polidori, A., Hu, S., Biswas, S., Delfino, R. J., and Sioutas, C.: Real-time characterization of particle-bound polycyclic aromatic hydrocarbons in ambient aerosols and from motor-vehicle exhaust, Atmos. Chem. Phys., 8, 1277, 2008.

Radola, B., Picaud, S., Vardanega, D., and Jedlovszky, P.: Analysis of Mixed Formic and Acetic Acid Aggregates Interacting with Water. A Molecular Dynamics Simulation Study, J. Phys. Chem. C, 121, 13 863-13 875, 2017.

Ras, M. R., Marce, R. M., and Borrull, F.: Volatile organic compounds in air at urban and industrial areas in the Tarragona region by thermal desorption and gas chromatography-mass spectrometry, Environ. Monit. Assess., 161, 389, 2009.

Reche, C., Querol, X., Alastuey, A., Viana, M., Pey, J., Moreno, T., Rodriguez, S., Gonzalez, Y., Fernandez-Camacho, R., de la Campa, A. M. S., de la Rosa, J., Dall'Osto, M., Prevot, A. S. H., Hueglin, C., Harrison, R. M., and Quincey, P.: New considerations for PM, Black Carbon and particle number concentration for air quality monitoring across different European cities, Atmos. Chem. Phys., 11, 6207, 2011.

Richter, H. and Howard, J. B.: Formation of polycyclic aromatic hydrocarbons and their growth to soot-a review of chemical reaction pathways, Prog Energy Combust Sci, 26, 565, 2000.

Riemer, N., Ault, A. P., West, M., Craig, R. L., and Curtis, J. H.: Aerosol mixing state: measurements, modeling, and impacts, Rev. Geophys., 57, 187, 2019. 
Ripoll, A., Pey, J., Minguillon, M. C., Perez, N., Pandolfi, M., Querol, X., and Alastuey, A.: Three years of aerosol mass, black carbon and particle number concentrations at Montsec (southern Pyrenees, 1570 m a.s.1.), Atmos. Chem. Phys., 14, 4279, 2014.

Rose, D., Wehner, B., Ketzel, M., Engler, C., Voigtlander, J., Tuch, T., and Wiedensohler, A.: Atmospheric number size distributions of soot particles and estimation of emission factors, Atmos. Chem. Phys., 6, 1021, 2006.

Rose, D., Gunthe, S. S., Su, H., Garland, R. M., Yang, H., Berghof, M., Cheng, Y. F., Wehner, B., Achtert, P., Nowak, A., Wiedensohler, A., Takegawa, N., Kondo, Y., Hu, M., Zhang, Y., Andreae, M. O., and Poschl, U.: Cloud condensation nuclei in polluted air and biomass burning smoke near the mega-city Guangzhou, China -Part 2: Size-resolved aerosol chemical composition, diurnal cycles, and externally mixed weakly CCN-active soot particles, Atmos. Chem. Phys., 11, 2817, 2011.

Rupakheti, D., Adhikary, B., Praveen, P. S., Rupakheti, M., Kang, S. C., Mahata, K. S., Naja, M., Zhang, Q. G., Panday, A. K., and Lawrence, M. G.: Pre-monsoon air quality over Lumbini, a world heritage site along the Himalayan foothills, Atmos. Chem. Phys., 17, $11041,2017$.

Sarkar, C., Roy, A., Chatterjee, A., Ghosh, S. K., and Raha, S.: Factors controlling the long-term (2009-2015) trend of PM 2.5 and black carbon aerosols at eastern Himalaya, India, Sci. Total Environ., 656, 280, 2019.

Schaap, M., Van Der Gon, H. A. C. D., Dentener, F. J., Visschedijk, A. J. H., Van Loon, M., ten Brink, H. M., Putaud, J. P., Guillaume, B., Liousse, C., and Builtjes, P. J. H.: Anthropogenic black carbon and fine aerosol distribution over Europe, J. Geophys. Res., 109, D18 207, 2004.

Shen, L. J., Li, L., Lu, S., Zhang, X. H., Liu, J. E., An, J. L., Zhang, G. J., Wu, B., and Wang, F.: Characteristics of black carbon aerosol in Jiaxing, China during autumn 2013, Particuology, 20, 10, 2015.

Stuart, S. J., Tutein, A. B., and Harrison, J. A.: A reactive potential for hydrocarbons with intermolecular interactions, J. Chem. Phys., 112, $6472,2000$.

Sun, C. and Bai, B.: Gas diffusion on graphene surfaces, Phys. Chem. C., 19, 3894, 2017.

Tao, J., Zhang, L. M., Cao, J. J., and Zhang, R. J.: A review of current knowledge concerning PM $_{2.5}$ chemical composition, aerosol optical properties and their relationships across China, Atmos. Chem. Phys., 17, 9485, 2017.

Trompetter, W. J., Grange, S. K., Davy, P. K., and Ancelet, T.: Vertical and temporal variations of black carbon in New Zealand urban areas during winter, Atmos. Environ., 75, 179, 2013.

Ueda, S., Nakayama, T., Taketani, F., Adachi, K., Matsuki, A., Iwamoto, Y., Sadanaga, Y., and Matsumi, Y.: Light absorption and morphological properties of soot-containing aerosols observed at an East Asian outflow site, Noto Peninsula, Japan, Atmos. Chem. Phys., 16, $2525,2016$.

Ueda, S., Osada, K., Hara, K., Yabuki, M., Hashihama, F., and Kanda, J.: Morphological features and mixing states of soot-containing particles in the marine boundary layer over the Indian and Southern oceans, Atmos. Chem. Phys., 18, 9207, 2018.

Volkamer, R., Ziemann, P. J., and Molina, M. J.: Secondary Organic Aerosol Formation from Acetylene $\left(\mathrm{C}_{2} \mathrm{H}_{2}\right)$ : seed effect on SOA yields due to organic photochemistry in the aerosol aqueous phase, Atmos. Chem. Phys., 9, 1907, 2009.

Wang, J. F., Ge, X. L., Chen, Y. F., Shen, Y. F., Zhang, Q., Sun, Y. L., Xu, J. Z., Ge, S., Yu, H., and Chen, M. D.: Highly time-resolved urban aerosol characteristics during springtime in Yangtze River Delta, China: insights from soot particle aerosol mass spectrometry, Atmos. Chem. Phys., 16, 9109, 2016.

Wang, Z.: Alignment of graphene nanoribbons by an electric field, Carbon, 47, 3050, 2009.

Wang, Z.: Chirality-dependent motion transmission between aligned carbon nanotubes, Carbon, 151, 130, 2019a.

Wang, Z.: Selective conduction of organic molecules via free-standing graphene, J. Phys. Chem. C, 123, 15 166, $2019 \mathrm{~b}$.

Wang, Z. and Devel, M.: Periodic ripples in suspended graphene, Phys. Rev. B, 83, 125 422, 2011. 
https://doi.org/10.5194/acp-2020-81

Preprint. Discussion started: 20 February 2020

(c) Author(s) 2020. CC BY 4.0 License.

(c) (1)

Wang, Z. and Philippe, L.: Deformation of doubly clamped single-walled carbon nanotubes in an electrostatic field, Phys. Rev. Lett., 102, $215501,2009$.

Wentzel, M., Gorzawski, H., Naumann, K. H., Saathoff, H., and Weinbruch, S.: Transmission electron microscopical and aerosol dynamical characterization of soot aerosols, J. Aerosol Sci., 34, 1347, 2003.

Yang, W. Q., Zhang, Y. L., Wang, X. M., Li, S., Zhu, M., Yu, Q. Q., Li, G. H., Huang, Z. H., Zhang, H. N., Wu, Z. F., Song, W., Tan, J. H., and Shao, M.: Volatile organic compounds at a rural site in Beijing: influence of temporary emission control and wintertime heating, Atmos. Chem. Phys., 18, $12663,2018$.

Yu, H., Li, W. J., Zhang, Y. M., Tunved, P., Dall'Osto, M., Shen, X. J., Sun, J. Y., Zhang, X. Y., Zhang, J. C., and Shi, Z. B.: Organic coating on sulfate and soot particles during late summer in the Svalbard Archipelago, Atmos. Chem. Phys., 19, 10 433, 2019.

Zhang, R. Y., Wang, G. H., Guo, S., Zarnora, M. L., Ying, Q., Lin, Y., Wang, W. G., Hu, M., and Wang, Y.: Formation of Urban Fine Particulate Matter, Chem. Rev., 115, 3803, 2015.

Zhao, Z., Kong, K. W., Wang, S. X., Zhou, Y. C., Cheng, D. J., Wang, W. C., Zeng, X. C., and Li, H.: Understanding hygroscopic nucleation of sulfate aerosols: combination of molecular dynamics simulation with classical nucleation theory, J. Phys. Chem. Lett., 10, 1126, 2019. 2012. 